\title{
FEATURE A public-private partnership to enhance the voluntary approach to nutrient stewardship
}

\author{
Douglas J. Lawrence, Lara Moody, and Frank B. Clearfield
}

D

espite growing evidence acknowledging the benefits of voluntary, incentive-based approaches to encourage nutrient stewardship, some organizations and agencies continue to be skeptical. However, among the fertilizer industry, many conservation organizations, and other agricultural groups, there is general agreement that the voluntary approach provides a catalyst for nutrient stewardship on agricultural land and that strategic opportunities exist to increase its effectiveness. One of the ways to realize opportunities associated with voluntary measures is enhanced collaboration between agricultural retailers and conservation districts as they work with farmers to plan and implement nutrient management practices.

To better understand the existing professional relationships between these groups, to evaluate the impact of their relationships on nutrient stewardship, and to identify strategies for improving their working relationships, agricultural retailer and conservation district employees were surveyed in 2013.

\section{BACKGROUND}

Among the many challenges facing agriculture is ensuring long-term, profitable production while also meeting society's additional economic and environmental priorities. The challenge for farmers (enhancing nutrient stewardship while producing food, fiber, and fuel) lies at the confluence of many powerful forces. These external forces include evolving commodity program policy; changing crop insurance rules; expanding federal, state, and local environmental regulations; uncertain commodity prices; rising production costs; changes in technology; shifting weather and climate patterns; threats from pests; and uncertain labor supply. Making production and stewardship

Douglas J. Lawrence is the managing partner of Blackwoods Group, LLC, Washington, DC. Lara Moody is the director of stewardship programs at The Fertilizer Institute, Washington, DC. Frank B. Clearfield is an independent social sciences consultant, Southport, North Carolina. decisions within this complex decisionmaking environment is difficult at best. If agricultural retailers and conservation districts work more closely together to inform farmers' nutrient stewardship decisions, environmental protection and profitable agriculture will be better served.

Loss of nutrients from farm fields is of increasing concern and has spawned discussion regarding an expanded role for regulation potentially affecting nutrient use in crop production systems. Recent examples of regulations that could affect agriculture include the US Environmental Protection Agency (USEPA) Total Daily Maximum Load for the Chesapeake Bay Watershed and USEPA's attempt to bypass state regulators and impose numeric nutrient criteria in Florida. Other states, like Maryland, already have requirements in place specifically addressing agricultural nutrient management.

A great deal of research has been undertaken to assess the contribution of agricultural sources of nutrients to the Gulf of Mexico, the Chesapeake Bay, and western Lake Erie, to name a few. For example, in 2007, USEPA reassessed Gulf of Mexico hypoxia and found that a reduction of $45 \%$ or more in nitrogen $(\mathrm{N})$ and phosphorous (P) delivered to the Gulf from all sources is needed to reduce the size of the hypoxic zone (USEPA 2007). As part of a broad set of recommendations, the USEPA Science Advisory Board recommended "improved management of nutrients by emphasizing infield nutrient management efficiency and effectiveness..." (USEPA 2008).

In October of 2012, the Des Moines Register published an article (Beeman 2012) that stated, "the nonprofit Iowa Environmental Council believes it may be time to require fertilizer-management plans of farmers, similar to the manuremanagement plans already required of many livestock producers." Craig Cox, senior vice president of the Environmental Working Group, is quoted in the article as saying,"We think it should be clear that solely relying on voluntary approaches isn't working. We've been doing this for 70 years. It isn't enough."
However, the voluntary, incentive-based approach to conservation policy has not been a static, monolithic endeavor over the past 70 years. Indeed, Congress has expanded and sharpened voluntary conservation policy in farm bills for decades. In order to institutionalize an ongoing evaluation of voluntary conservation programs, Congress directed the USDA Natural Resources Conservation Service (NRCS) in the 2002 Farm Bill Mangers Report to undertake an assessment of farm bill conservation programs. Based on this directive, the NRCS has led an effort known as the Conservation Effects Assessment Project (CEAP). A recent CEAP cropland assessment report suggests that farmers have made significant progress in reducing the externalities of crop production under the voluntary, incentives-based approach. The 2013 CEAP report for the Chesapeake Bay (USDA NRCS 2013a) indicates that for the period between the first CEAP farmer survey (data collected from 2003 to 2006) and the second farmer survey in 2011 (which is prior to implementation of the Chesapeake Bay Total Maximum Daily Load), farmers adopted conservation measures that reduced edge-of-field sediment losses by a remarkable $63 \%$. Sediment losses from cropland dropped, in roughly five years, from $12.3 \mathrm{t} \mathrm{ha}^{-1} \mathrm{y}^{-1}\left(5.5 \mathrm{tn} \mathrm{ac}^{-1} \mathrm{yr}^{-1}\right)$ to $4.3 \mathrm{t} \mathrm{ha}^{-1} \mathrm{y}^{-1}\left(1.9 \mathrm{tn} \mathrm{ac}^{-1} \mathrm{yr}^{-1}\right)$, which means 13.7 million $t$ (15.1 million $t n)$ of sediment are being kept out of streams, rivers, and the Bay each year. Additionally, farmers have reduced edge-of-field surface runoff of $\mathrm{N}$ by $38 \%$, reduced subsurface losses of $\mathrm{N}$ by $12 \%$, and reduced $\mathrm{P}$ losses by $45 \%$. Agriculture Secretary Tom Vilsack said, "This report demonstrates that voluntary conservation practices made possible through the Farm Bill can have a substantial impact on limiting nutrient and sediment runoff from farms in the Chesapeake Bay Watershed and across the nation" (USDA NRCS 2013b).

A promising partnership is emerging that could materially help farmers improve nutrient stewardship and maintain profitability. This informal partnership 
brings farmers, conservation districts, and agricultural retailers together to leverage the strengths of each group. Farmers bring their knowledge of crop production and interest in natural resource stewardship to the table, conservation districts bring state-of-the-art skills associated with comprehensive conservation planning and implementation, and agricultural retailers bring cutting-edge knowledge about nutrient stewardship.

\section{PARTNERING TO IMPROVE NUTRIENT STEWARDSHIP}

The 4R nutrient stewardship initiative is an innovative, science-based approach that can enhance environmental protection and increase farmer profitability. The $4 \mathrm{R}$ approach to nutrient stewardship integrates the Right nutrient source, at the Right rate, at the Right time, and in the Right place. Without solely focusing on application rate, the 4Rs utilize suites of fertilizer best management practices to address the economic, environmental, and social dimensions of nutrient management.

To help farmers address the challenge of enhanced nutrient stewardship, The Fertilizer Institute has been working with the International Plant Nutrition Institute, the International Fertilizer Industry Association, and the Canadian Fertilizer Institute to advance $4 \mathrm{R}$ nutrient stewardship. The goals of this initiative include establishing $4 \mathrm{R}$ nutrient stewardship as a recognizable strategy for economic, social, and environmental sustainability and expanding adoption of 4R nutrient stewardship. The effort has grown in recent years with nearly 60 partners including corporations as well as environmental and conservation organizations.

To gain a better understanding of the existing relationship between conservation districts and agricultural retailers, the National Council of Farmer Cooperatives, the Agricultural Retailers Association, the National Association of Conservation Districts, the American Society of Agronomy-Certified Crop Advisors (CCAs), and The Fertilizer Institute conducted a survey of agricultural retailers and soil and water conservation district staff. The goals of the survey were to (1) identify the strengths of the agricultural retailer-conservation district working relationship, (2) identify opportunities to improve the agricultural retailer-conservation district working relationship, (3) solicit strategies for these groups to work more closely together, and (4) establish baseline information about the use of $4 \mathrm{R}$ nutrient stewardship practices.

\section{SURVEY PROCESS}

The 4R nutrient stewardship survey was distributed in late February of 2013. An invitation to participate in the nutrient stewardship survey was sent to approximately 2,600 field-level agricultural retailer employees and 2,600 conservation district employees. The response rates were similar, with 396 agricultural retailer employees $(15.2 \%)$ and 481 conservation district staff (18.5\%) responding to the surveys.

Conservation district employees in the upper Midwest, Midwest, Mid-Atlantic, and parts of the South were represented in the survey. Few conservation district employees from the West responded to the survey. Agricultural retailer responses were more concentrated than conservation district responses and came largely from the upper Midwest, Midwest, and the ArkansasTennessee part of the Mississippi Delta region. Both groups work with producers who grow corn (Zea Mays L.), soybeans (Glycine max [L.] Merr.), and wheat (Triticum aestivum L.). The groups also service similarly sized areas of 69,000 ha $(170,000 \mathrm{ac})$ for conservation district staff and 75,000 ha $(185,000 \mathrm{ac})$ for agricultural retailers. Fifty-five percent of agricultural retailers are CCAs, and not unexpectedly, $5 \%$ of conservation district employees are CCAs.

The survey asked respondents 25 questions that included a variety of categorical response and open-ended questions. The survey responses enabled the assessment team to evaluate each group's knowledge of nutrient stewardship, the working relationship between the groups, the type of $4 \mathrm{R}$ practices they recommend to their customers, their perception of the environmental and economic benefits of $4 \mathrm{R}$ practices, and barriers to $4 \mathrm{R}$ nutrient stewardship adoption. Open-ended questions gave respondents an opportunity to provide their ideas on improving collaboration, overcoming barriers, identifying training needs, and recommending additional $4 \mathrm{R}$ tools.

\section{SURVEY FINDINGS}

The survey found that the desire to have a "positive environmental impact" and "customer loyalty" are very important to both conservation district employees and agricultural retailers. The groups agreed that the producers' perceived costs of $4 \mathrm{R}$ practices and farming traditions serve as major barriers to adopting nutrient stewardship practices. The survey also found other similarities between the groups, including the desire to improve information sharing through regular meetings, joint training, and improving professional relationships. While a high percentage of both groups want to see this occur, the content of the information shared would be different. Agricultural retailers want cost-share and planning information from conservation district staff, while district staff would like detailed information about the $4 \mathrm{Rs}$ from agricultural retailers. These findings can serve as a foundation on which to establish ways to aid collaboration between the two groups.

Although differences exist between the two groups of survey respondents, these differences should not be a significant obstacle to improving collaboration on nutrient stewardship services to farmers. For example, in terms of current working partnerships, the agricultural retailers identified CCAs and other agricultural retailers as their top collaborators. In contrast, the conservation districts identified their top two partners as NRCS and state agricultural and environmental agencies. The respondents agreed that a major barrier to working closer together was differing organizational objectives. However, each organization brings a unique set of traditions, resources, skills, and history that when combined could strengthen both groups and improve their ability to address nutrient stewardship issues with farmers.

With respect to recommending practices to agricultural producers, each group makes categorically different recommendations. Agricultural retailers recommend more specific 4R nutrient stewardship practices, such as split nutrient applications and applying $\mathrm{N}$ stabilizers, while conservation districts recommend a broader array of practices, such as conservation tillage and planting cover crops. These distinct recommendations are likely the basis for each 
group's diverse rating of the economic and environmental benefits of practices.

The two groups agreed that the major barriers faced by farmers in adopting additional 4R nutrient stewardship practices are perceived cost, resistance to change, and profit motive. Regarding anticipation of federal and state regulations, both groups rated the likelihood of future commercial fertilizer regulation high, but agricultural retailers rated their likelihood somewhat higher. The groups also agreed with each other (and with previous research) that the best way to convey information about the 4Rs was through on-farm demonstrations or field days. This tried and true technique would likely be well received by farmers who want to not only see the practices applied, but also listen to discussions of research results. Finally, and most valuable, farmers also want to talk with one another about their particular experiences.

The overarching goal of encouraging agricultural retailers and conservation districts to work closer together is to help advance the voluntary nutrient stewardship approach. Improved information exchange can be achieved with a commitment to share information by organizational leadership at the national, regional, and local levels. Agricultural retailers would like information on cost-sharing programs, nutrient plans, farm plans, and technology from district staff. District staff would like information from agricultural retailers on fertilizer best management practice cost data and general information about their role in nutrient management. An area of interest to both groups, but also one that remains challenging, is data and electronic record sharing. Understandably, there are confidentiality concerns that need to be resolved before proceeding with developing software that facilitates data sharing.

\section{CONCLUSION}

Perhaps one of the most important findings from the survey is that both groups rated having a "positive environmental impact" very high. The groups also agreed that perceived cost and farming traditions are major barriers to producers adopting nutrient stewardship practices. These findings should serve as an excellent foundation for collab- oration on helping farmers adopt voluntary nutrient stewardship.

Although there are many differences between the two groups, these differences should not be an obstacle to improved collaboration with farmers to improve nutrient stewardship. Because each group has distinct, yet complementary strengths derived from their differing objectives, there is great potential for collaboration based on a shared desire to have a "positive environmental impact." Opportunities exist to improve collaboration between the two groups through improved information exchange, but vehicles to accomplish this need to be created. Currently, about $40 \%$ of respondents in each group receive no information from the other group. More importantly, the unmet demand for information sharing is extraordinary, with $63 \%$ of conservation district employees and $82 \%$ of agricultural retailers indicating a desire for additional information from the other group. Agricultural retailers and conservation districts agree on methods to improve their working relationship: sharing information and having periodic, joint meetings. Both groups gave their highest ratings to demonstrations and field days.

Federal, state, and local government, especially USDA's NRCS, Agricultural Research Service, and National Institute of Food and Agriculture, can play significant roles in fostering agricultural retailer-conservation district collaboration. The public sector role includes actions and polices that support sharing technical information as well as providing training that includes both conservationists and agricultural retailers. The public sector can also develop information on the economic benefits and costs associated with nutrient stewardship practices. The development of secure data sharing protocols that honor farmer confidentiality and the development of infield plant and soil nutrient sensors are also essential to making the process of planning and applying nutrient stewardship more efficient for farmers.

The experiences of Charles Glover, president of the Arkansas Association of Conservation Districts, support the findings of the 4R nutrient stewardship survey:

I have long believed that crop consultants could be a driving force for conservation if they had more knowledge about conservation practices and programs. Consultants are the ones that have intimate knowledge of their clients' farms, and being able to advise them on cost-share practices would be an excellent selling point to their services. I have been looking into providing that sort of information to consultants in Arkansas in hopes they could become ambassadors for conservation. (Personal communication, December 21, 2013)

The 4R nutrient stewardship survey not only supports the vision laid out by Charles Glover-crop consultants becoming ambassadors for conservation-it also provides practical recommendations for realizing this vision. Finally, the agricultural retailer and conservation district partnership has the potential to enhance the voluntary approach, accelerate the adoption of 4R nutrient stewardship practices, reduce nutrient run-off, and lower the potential for increased nonpoint source regulatory actions.

\section{REFERENCES}

Beeman, P. 2012. Some call for tougher fertilizer regulations. Des Moines Register. October 29, 2012. http://www.desmoinesregister. com/article/20121029/NEWS/310290017/ Some-call-tougher-fertilizer-regulations.

USEPA (Environmental Protection Agency). 2008. Gulf Hypoxia Action Plan 2008. http:// water.epa.gov/type/watersheds/named/ msbasin/upload/2008_8_28_msbasin_ ghap2008_update082608.pdf.

USEPA. 2007. Hypoxia in the Northern Gulf of Mexico:An Update by the EPA Science Advisory Board. http://water.epa.gov/type/watersheds/ named/msbasin/upload/2008_1_31_msbasin_ sab_report_2007.pdf.

USDA NRCS (Natural Resources Conservation Service). 2013a. Impacts of Conservation Adoption on Cultivated Acres of Cropland in the Chesapeake Bay Region, 2003-2006 to 2011. http://www.nrcs.usda.gov/wps/ portal/nrcs/detail/national/technical/nra/ ceap/?cid=stelprdb1240074.

USDA NRCS. 2013b. Report shows Farm Bill conservation practices reduce runoff of nutrient, sediment in Chesapeake Bay watershed. News Release. December 5, 2013. http://www. nrcs.usda.gov/wps/portal/nrcs/detail/national/ newsroom/releases/?cid=STELPRDB1240087. 